\title{
Evaluation of nematode suppression and yield improvement potential of organic substances in sweet potato crop
}

\author{
Osei, K., J. Adomako., Y. Danso., JS. Asante., B. Abugri \\ Plant Health Division, Council for Scientific and Industrial Research-Crops Research Institute, Kumasi, Ghana \\ Corresponding author; oseikingsley4@gmail.com
}

Original submitted in on 27 ${ }^{\text {th }}$ September 2017. Published online at www.m.elewa.org on 30 th November 2017 https://dx.doi.org/10.4314/jab.v119i1.4

\begin{abstract}
Objective: To investigate nematode suppression and yield improvement potential of two organic materials; poultry manure and chopped neem leaves in sweet potato production.

Methodology and results: A factorial experiment mounted on Randomized Complete Block Design was conducted in 2014 and 2015 at Atebubu and Wenchi, prominent farming communities in the Brong Ahafo region of Ghana. The organic materials were applied on two sweet potato varieties; Apomuden and Santom pona. Poultry manure and neem leaves weighing $100 \mathrm{~g}$ and $30 \mathrm{~g}$ respectively were applied per stand. Plant population, nematodes population per $200-\mathrm{cm}^{3}$ soil at planting and harvest, tuber galls, vine dry matter weight at harvest and yield were analyzed. Significantly, higher $(P<0.05)$ plant population was recorded at Wenchi compared to Atebubu in 2015. Control plots recorded significantly highest plant parasitic nematodes compared with the poultry manure and neem leaf treatments. Consistently, neem leaf amended plots recorded lowest population levels $(67,68$ and 33$) \%$ and (84 and 84 ) \% less Meloidogyne spp., $P$. brachyurus and $H$. multicintus and Meloidogyne spp., and $P$. brachyurus were extracted from neem leaf amended Santom pona plots compared with the control of Santom pona at Atebubu and Wenchi respectively. Poultry manure on Santom pona recorded the highest gall index, which was $78.8 \%$ more than observed on Santom pona treated with neem leaves. Neem leaf correlated positively with Apomuden and recorded the highest yield in 2014 at Atebubu, which was approximately $93 \%$ higher than the control of Santom pona, which yielded 0.9 t/ha. The yield of neem leaf on Apomuden was significantly higher (35\% and $41 \%$ ) than neem leaf on Santom pona in 2014 and 2015 at Atebubu and Wenchi respectively.

Conclusion and application of findings: Nematode management with synthetic products must be discouraged on grounds of mammalian toxicity and environmental degradation. The use of organic amendments should be encouraged for suppression of nematode population densities, improvement in yield and environmental friendliness. The latter option is sustainable and more importantly, tuber crops produced with organic amendments would be free from chemical residues.
\end{abstract}

Key words: Neem leaves, nematodes, poultry manure, sweet potato varieties 


\section{INTRODUCTION}

Sweet potato (Ipomoea batatas L. (Lam) is a member of the morning glory family (Convolvulaceae) and not related to the common potato (Solanaceae). It exhibits heterozygosity, wide variability of morphological traits and nutritional quality, conferring on it genetic diversity (Afuape et al., 2006). Sweet potato provides good ground cover, prevents soil erosion and a source of supplementary carbohydrate diet to yam and cassava (Janssens, 2001). It could be regarded as a poverty reduction crop as it grows on soils with limited fertility and has a short growth period with a high yield. It has been reported that sweet potato possesses higher $\beta$ carotene content than any other root and tuber crop (Suda et al., 1999). In addition, the crop has tremendous medicinal properties. In Japan, sweet potato has been successfully used to treat diabetic patients (Ludvik et al., 2003). In addition, sweet potatoes are used for managing menstrual problems and osteoporosis. Other medicinal uses include reducing diverticulosis, which is an ailment of the intestines; gallbladder complaints; and arthritis (Kaniecki, 2011). The versatility of the crop stretches to the corridors of industry where it is used for starch (Betiku \& Adesina, 2013), microbial hydrogen (Yokoi et al., 2001) and ethanol fuel (Ziska, 2008). The numerous benefits that could be derived from the cultivation of the crop has earned it the accolade "the green golden mine" that should be developed (Jiang et al., 2005). However, the cultivation of this life-

\section{MATERIALS AND METHODS}

Study site: The study was conducted on farmer fields at two locations in the Brong Ahafo region of Ghana. The locations which are prominent farming communities with large populations and vibrant local markets were; Atebubu $\left(7^{\circ} 38^{\prime} \mathrm{N} 1^{\circ} 4^{\prime} \mathrm{W}\right)$ and Wenchi $\left(7^{\circ} 44^{\prime} \mathrm{N} 2^{\circ} 6^{\prime} \mathrm{W}\right)$ both in the forest-savannah transitional zone.

Source of sweet potato varieties: Two sweet potato varieties (Apomuden and Santom pona) were obtained from the Sweet Potato Improvement Programme under the Roots and Tubers Division of the CSIR-Crops Research Institute, Ghana, for the investigation.

Source and preparation of treatments: Two organic materials (poultry manure and neem leaves) were saving crop is seriously hampered by plant parasitic nematodes (PPN) which are most difficult pest problems evaluated in every agricultural economy. In sweet potato production, four PPN, (Meloidogyne spp., Rotylenchulus spp., Pratylenchus spp. and Ditylenchus spp.) are economically important. Nematodes represent a significant problem in sweet potato production causing reduction in yield and quality in storage roots (Cervantes-Flores, 2000). According to (Suzuki et al., 2012), sweet potato is highly susceptible to the southern root-knot nematode, Meloidogyne incognita that causes severe damage to the tuberous roots. Similarly, (Wang, 2016) observed that the reniform nematode, Rotylenchulus reniformis, causes root necrosis resulting in severe root pruning, stunted plants and cracking on the tuber. According to (Abel et al., 2007), R. reniformis caused $24 \%$ yield loss on sweet potato while Pratylenchus brachyurus reduced leaf growth on shoots (Agu 2004). Several authors including; (Sun et al., 1998) and (Wang et al., 1995) implicated Ditylenchus dipsaci as causing water loss and shrinkage in sweet potato tubers, reduction in size and number of starch grains. An experiment involving organic materials was therefore designed to evaluate the potential of poultry manure and crude neem (Azadiractha indica) leaves in suppressing the population build-up of nematodes and improving the yield of sweet potato.

obtained from the respective experimental locations before the start of the experiment. Fresh neem (Azadirachta indica) leaves were chopped into $1-\mathrm{cm}$ pieces using a pair of scissors. Thirty grams $(30 \mathrm{~g})$ of the chopped neem leaves and $100 \mathrm{~g}$ of poultry manure were respectively weighed with an electronic scale into separate packaging bags for easy transportation to the experimental sites.

Soil sampling, extraction and identification of nematodes: Soil samples were collected at two times; planting and harvest. At planting, experimental site, samples were collected. However, at harvest, three soil samples $\left(200 \mathrm{~cm}^{3}\right) /$ plot were randomly collected with the 
aid of a $5 \mathrm{~cm}$ diameter auger to a depth of $20 \mathrm{~cm}$ across the locations. The purpose was to determine the diversity and density of nematode communities before and after the application of treatments. Nematodes were extracted using the modified Baermann tray method (Whitehead \& Hemming, 1965) and the various nematode taxa were identified under a compound microscope at a magnification of $100 \mathrm{x}$

Experimental set up: The factorial experiment was laid out in a Randomized Complete Block Design (RCBD) with four replications at both locations. Plot size for each replication was $(3 \times 4) \mathrm{m}$. Planting was done at a distance of $1 \mathrm{~m}$ by $1 \mathrm{~m}$ with sweet potato vines, each measuring $15 \mathrm{~cm}$. Neem leaves and poultry manure weighing $30 \mathrm{~g}$ and $100 \mathrm{~g}$ respectively were applied per stand and thoroughly mixed in the soil at planting. No organic material was applied to the control plots. Weed

\section{RESULTS AND DISCUSSION}

Four economically important plant parasitic nematodes (PPN) were encountered on the experimental plots at the two locations in 2014 before planting of the sweet potato crop. The nematodes in order of abundance were, Meloidogyne spp., Pratylenchus brachyurus, Rotylenchulus reniformis and Helicotylenchus multicintus. (Data not given). All the nematode species encountered belong to the Order Tylenchida. The differences in population levels could be attributed to differences in fecundity levels of the different nematode species and the types of weed species on the plots before the establishment of the experiments since weeds are alternate hosts of nematodes (Khan \& Khan, 1985). Treatments did not influence plant population at the two locations in the two years of experimentation. Factors that influence plant population include; viability of the planting material, adequate rainfall, seed bed preparation and the native fertility status of the plots. Plant population is an important parameter in crop husbandry since yield is a function of plant population (Akber et al., 2010). Similarly, treatments did not influence vine weight as no differences were recorded. Of the four PPN encountered on the management on each plot was done manually by hand picking.

Data collection and analysis: Plant population, nematodes population per $200-\mathrm{cm}^{3}$ soil at planting and harvest, tuber galls using six plants in the middle rows, vine dry matter weight at harvest and yield were analyzed. Yield, being continuous data, was not transformed, but nematode count and index-based data were In $(x+1)$ and square root $\sqrt{ }(x+1$ transformed respectively to improve homogeneity of variance before analysis. Statistical analysis was performed using General Statistics (Genstat 8 ) version 12.0 (Lawes Agricultural Trust, VSN International). Means were separated using Fisher's least significance test at $\alpha=$ 0.05 .

experimental plots at planting, three; Meloidogyne spp., Pratylenchus brachyurus and Helicotylenchus multicintus and two species; Meloidogyne spp., and $P$. brachuyrus were isolated from soil samples at Atebubu and Wenchi respectively at harvest in 2014. Poultry manure and neem leaf amended plots recorded significantly lower nematode densities compared with the control. Consistently, neem leaf amended plots recorded lowest nematode population levels. It was observed that $(67,68$ and 33$) \%$ and $(84$ and 84$) \%$ less Meloidogyne spp., $P$. brachyurus and $H$. multicintus and Meloidogyne spp., and P. brachyurus were extracted from neem leaf on Santom pona treatments than the control of Santom pona at Atebubu and Wenchi respectively (Table 1). The lethal effect of neem leaf has previously been demonstrated. Juveniles of M. incognita exposed to $20 \%$ and $30 \%$ concentrations of the fresh neem leaf extracts showed $50 \%$ and $90 \%$ mortality within 15 min. of exposure respectively. By 30 min, mortality had reached almost $100 \%$ in contrast to about $10 \%$ mortality recorded in the control after $24 \mathrm{hr}$ (Agbenin et al., 2005). 
Osei et al., J. Appl. Biosci. 2017 Evaluation of nematode suppression and yield improvement potential of organic substances in sweet potato crop

Table 1: Plant parasitic nematodes per $200 \mathrm{~cm}^{3}$ rhizosphere soil at Atebubu and Wenchi at harvest (2014)

\begin{tabular}{|l|l|c|r|r|r|}
\hline \multirow{2}{*}{ Treatment } & \multicolumn{3}{|c|}{ Atebubu } & \multicolumn{2}{c|}{ Wenchi } \\
\cline { 2 - 6 } & Meloi & Praty & Heli & Meloi & Praty \\
\hline PM + Apomuden & $22(1.2) \mathrm{a}$ & $9(0.8) \mathrm{b}$ & $9(0.8) \mathrm{a}$ & $13(0.9) \mathrm{b}$ & $8(0.7) \mathrm{a}$ \\
PM + Santom pona & $22(1.2) \mathrm{a}$ & $16(1.2) \mathrm{c}$ & $4(0.5) \mathrm{a}$ & $11(0.9) \mathrm{b}$ & $9(0.8) \mathrm{a}$ \\
NL + Apomuden & $19(1.1) \mathrm{a}$ & $3(0.3) \mathrm{a}$ & $5(0.6) \mathrm{a}$ & $3(0.4) \mathrm{a}$ & $5(0.6) \mathrm{a}$ \\
NL + Santom pona & $12(1.0) \mathrm{a}$ & $7(0.7) \mathrm{b}$ & $6(0.6) \mathrm{a}$ & $3(0.4) \mathrm{a}$ & $5(0.6) \mathrm{a}$ \\
Apomuden Control & $22(1.2) \mathrm{a}$ & $28(1.4) \mathrm{d}$ & $31(1.1) \mathrm{b}$ & $26(1.4) \mathrm{c}$ & $11(0.8) \mathrm{b}$ \\
Santom pona Control & $37(1.7) \mathrm{b}$ & $22(1.3) \mathrm{c}$ & $9(0.8) \mathrm{a}$ & $19(1.3) \mathrm{b}$ & $32(1.2) \mathrm{c}$ \\
\hline Mean & 22.3 & 14.2 & 10.7 & 12.5 & 11.7 \\
LSD [1n(x+1)] & $(0.5)$ & $(0.1)$ & $(0.3)$ & $(0.4)$ & $(1.0)$ \\
\hline
\end{tabular}

Data are means of four replications. Transformed data used in analysis in parentheses. Means followed by the same letters are not significantly different at $5 \%$ probability level. LSD = Least significant difference. Meloi $=$ Meloidogyne species, Praty $=$ Pratylenchus brachyurus and Heli = Helicotylenchus multicintus

The control of Apomuden recorded the highest nematode densities which were $(76,91,62$ and 98$) \%$ more than densities isolated from the rhizosphere of Apomuden amended with neem leaf regarding Meloidogyne spp., $P$. brachyurus, $H$. multicintus and $R$. reniformis respectively in 2015 at Atebubu (Table 2). Poultry manure on Apomuden on the other hand recorded $(309,333,43$ and 84) \% less Meloidogyne spp., $P$. brachyurus, $H$. multicintus and $R$. reniformis than the control of
Apomuden respectively. A similar trend was observed at Wenchi in 2015. The difference was that the highest nematode densities were isolated from the control of Santom pona and the least densities from neem leaf on Santom pona (Table 3). The results indicate the need for management interventions to reduce nematodes population build up during the planting season. Nematode infection negatively affects yield and quality of tuber crops (Moura, 1997; Garrido et al., 2003).

Table 2: Plant parasitic nematodes per $200 \mathrm{~cm}^{3}$ rhizosphere soil at Atebubu at harvest (2015)

\begin{tabular}{|l|c|c|l|l|}
\hline Treatment & Meloi & Praty & Heli & Roty \\
\hline PM + Apomuden & $881(2.7) \mathrm{a}$ & $683(2.8) \mathrm{b}$ & $236(2.2) \mathrm{b}$ & $330(2.3) \mathrm{b}$ \\
$\mathrm{PM}+$ Santom pona & $1159(2.9) \mathrm{a}$ & $675(2.7) \mathrm{b}$ & $199(1.4) \mathrm{a}$ & $372(2.5) \mathrm{b}$ \\
$\mathrm{NL}+$ Apomuden & $789(2.5) \mathrm{a}$ & $259(2.4) \mathrm{a}$ & $128(1.2) \mathrm{a}$ & $11(0.2) \mathrm{a}$ \\
$\mathrm{NL}+$ Santom pona & $732(2.5) \mathrm{a}$ & $231(2.3) \mathrm{a}$ & $110(1.1) \mathrm{a}$ & $236(2.2) \mathrm{a}$ \\
Apomuden Control & $3314(3.4) \mathrm{b}$ & $2956(3.4) \mathrm{C}$ & $338(2.4) \mathrm{b}$ & $607(3.8) \mathrm{c}$ \\
Santom pona Control & $1159(2.9) \mathrm{a}$ & $894(2.9) \mathrm{b}$ & $259(2.2) \mathrm{b}$ & $369(2.5) \mathrm{b}$ \\
\hline Mean & 1339 & 949.7 & 211.7 & 320.8 \\
LSD $[1 \mathrm{n}(\mathrm{x}+1)]$ & $(0.4)$ & $(0.4)$ & $(1.0)$ & $(1.1)$ \\
\hline
\end{tabular}

Data are means of four replications. Transformed data used in analysis in parentheses. Means followed by the same letters are not significant at $5 \%$ probability level. NS = No significance. LSD = Least significant difference. Meloi = Meloidogyne species, Praty = Pratylenchus brachyurus, Heli = Helicotylenchus multicintus and Roty $=$ Rotylenchulus reniformis 

organic substances in sweet potato crop

Table 3: Plant parasitic nematodes per $200 \mathrm{~cm}^{3}$ rhizosphere soil at Wenchi at harvest (2015)

\begin{tabular}{|l|l|l|l|l|}
\hline Treatment & Meloi & Praty & Heli & Roty \\
\hline PM + Apomuden & $642(2.8) \mathrm{b}$ & $169(1.5) \mathrm{b}$ & $144(1.7) \mathrm{b}$ & $36(0.6) \mathrm{a}$ \\
$\mathrm{PM}+$ Santom pona & $615(2.7) \mathrm{b}$ & $196(1.7) \mathrm{b}$ & $239(2.1) \mathrm{c}$ & $16(0.4) \mathrm{a}$ \\
$\mathrm{NL}+$ Apomuden & $460(2.2) \mathrm{a}$ & $66(1.2) \mathrm{a}$ & $15(0.4) \mathrm{a}$ & $33(0.5) \mathrm{a}$ \\
$\mathrm{NL}+$ Santom pona & $451(2.2) \mathrm{a}$ & $72(1.3) \mathrm{a}$ & $16(0.4) \mathrm{a}$ & $17(0.4) \mathrm{a}$ \\
Apomuden Control & $690(2.8) \mathrm{b}$ & $370(2.4) \mathrm{C}$ & $376(2.5) \mathrm{d}$ & $42(0.9) \mathrm{b}$ \\
Santom pona Control & $915(3.1) \mathrm{c}$ & $398(4.4) \mathrm{c}$ & $268(2.3) \mathrm{c}$ & $290(2.4) \mathrm{c}$ \\
\hline Mean & 595.5 & 211.8 & 176.3 & 192.3 \\
LSD $[1 \mathrm{n}(\mathrm{x}+1)]$ & $(0.2)$ & $(0.3)$ & $(0.3)$ & $(0.4)$ \\
\hline
\end{tabular}

Data are means of four replications. Transformed data used in analysis in parentheses. Means followed by the same letters are not significant at $5 \%$ probability level. NS $=$ No significance. $L S D=$ Least significant difference. Meloi $=$ Meloidogyne species, Praty = Pratylenchus brachyurus, Heli = Helicotylenchus multicintus and Roty $=$ Rotylenchulus reniformis

During the 2014 harvest of sweet potato, tuber gall index ranged from 2.5 to 3.0 in which there were no differences amongst the treatments evaluated at Wenchi. Significant differences were however observed in tuber galling at Atebubu. Poultry manure on Santom pona recorded the highest gall index, which was $78.8 \%$ more than observed on Santom pona treated with neem leaves (Table 4). In 2015, tuber-galling situation was not observed at Wenchi

Table 4: Sweet potato tuber galling index at Atebubu and Wenchi (2014).

\begin{tabular}{|l|l|l|}
\hline Treatment & Atebubu & Wenchi \\
\hline PM + Apomuden & $1.0(1.0) \mathrm{a}$ & $3.0(1.6) \mathrm{NS}$ \\
$\mathrm{PM}+$ Santom pona & $4.7(1.9) \mathrm{b}$ & $2.6(1.5)$ \\
$\mathrm{NL}+$ Apomuden & $2.3(1.3) \mathrm{bc}$ & $2.3(1.5)$ \\
$\mathrm{NL}+$ Santom pona & $1.0(1.0) \mathrm{a}$ & $1.7(1.4)$ \\
Apomuden Control & $1.1(1.0) \mathrm{a}$ & $2.5(1.5)$ \\
Santom pona Control & $2.6(1.5) \mathrm{bc}$ & $2.4(1.5)$ \\
\hline Mean & 2.1 & 2.4 \\
$\mathrm{LSD}[\sqrt{ }(1+0.5)]$ & $(0.02)$ & $(1.0)$ \\
\hline
\end{tabular}

Data are means of four replications. Transformed data used in analysis in parenthesis. LSD = Least significant difference

Table 5. Sweet potato tuber galling index at Atebubu (2015).

\begin{tabular}{|l|l|}
\hline Treatment & Atebubu \\
\hline PM + Apomuden & $3.0(1.7) \mathrm{a}$ \\
PM + Santom pona & $1.0(1.0) \mathrm{b}$ \\
$\mathrm{NL}+$ Apomuden & $1.2(1.1) \mathrm{b}$ \\
$\mathrm{NL}+$ Santom pona & $1.0(1.0) \mathrm{b}$ \\
Apomuden Control & $1.5(1.2) \mathrm{a}$ \\
Santom pona Control & $1.0(1.0) \mathrm{b}$ \\
\hline Mean & 1.4 \\
LSD $[\sqrt{ }(1+0.5)]$ & $(0.05)$ \\
\hline
\end{tabular}

Data are means of four replications. Transformed data used in analysis in parenthesis. LSD = Least significant difference

Sweet potato yields were generally higher in 2014 at both locations than in 2015. The significantly lower yields in 2015, was occasioned by poor rainfall pattern, which attended the crop season. The control treatments of but a trend similar to what happened in 2014 occurred at Atebubu. Poultry manure on Apomuden recorded the highest tuber gall index, which was $60 \%$ more than galls on poultry manure treated Apomuden tubers. It could therefore be stated that neem leaves were more effective in protecting sweet potato tubers against galls caused by Meloidogyne spp.(Table 5) 
control of Santom pona which yielded 0.9t/ha (Table 6). The yield of neem leaf on Apomuden was significantly higher (35\% and $41 \%$ ) than neem leaf on Santom pona in 2014 and 2015 at Atebubu and Wenchi respectively. Neem leaf treatments out-yielded poultry manure treatments. The findings of the current study are in concert with the observation of Pun et al. (2005) who reported that treatment-containing Azadirachtin significantly reduced attack of okra pests and increased yield. Neem leaf and poultry manure treatments outyielded the control plots, which demonstrated the influence of treatments on yield.

Table 6: Sweet potato tuber yield (tons /ha) at Atebubu and Wenchi in 2014 and 2015

\begin{tabular}{|l|l|l|l|l|}
\hline \multirow{2}{*}{ Treatment } & \multicolumn{2}{|c|}{2014} & \multicolumn{2}{c|}{2015} \\
& Atebubu & \multicolumn{2}{c|}{ Wenchi } & \multicolumn{2}{c|}{ Atebubu } & \multicolumn{1}{c|}{ Wenchi } \\
\hline PM + Apomuden & $7.5 \mathrm{~b}$ & $4.4 \mathrm{NS}$ & $2.1 \mathrm{~b}$ & $2.1 \mathrm{c}$ \\
PM + Santom pona & $8.7 \mathrm{~b}$ & 3.7 & $2.9 \mathrm{c}$ & $1.5 \mathrm{~b}$ \\
NL + Apomuden & $12.6 \mathrm{C}$ & 4.1 & $3.8 \mathrm{~d}$ & $3.9 \mathrm{~d}$ \\
NL + Santom pona & $8.1 \mathrm{~b}$ & 4.4 & $3.7 \mathrm{~d}$ & $2.3 \mathrm{c}$ \\
Apomuden Control & $5.0 \mathrm{a}$ & 1.8 & $1.4 \mathrm{a}$ & $1.5 \mathrm{~b}$ \\
Santom pona Control & $4.9 \mathrm{a}$ & 1.7 & $1.6 \mathrm{a}$ & $0.9 \mathrm{a}$ \\
\hline Mean & 7.8 & 3.4 & 2.6 & 2.0 \\
LSD & 2.2 & 2.9 & 0.2 & 0.1 \\
\hline
\end{tabular}

Data are means of four replications. Means followed by the same letters are not significant at $5 \%$ probability level. NS = Nonsignificance. LSD = Least significant difference

\section{CONCLUSION}

For sustainable crop husbandry, PPN must be managed effectively. Nematodes management with synthetic products must be discouraged on grounds of mammalian toxicity and environmental degradation. The use of

\section{ACKNOWLEDGEMENTS}

Authors are grateful to the West Africa Agricultural Productivity Programme for the financial support to carry

\section{REFERENCES}

Abel, CA., Adams, LC., Stetina, SR. (2007). Sweet potato yield reduction caused by reniform nematode in the Mississipi delta. Plant Health Programme DOI: 10.1094/PHP-2007-1115-01-RS.

Afuape, SO., Okocha, Pl., Nwauzor, EC, Nwankwo, IM., Njoku, DJ. (2006). Evaluation of new sweet potato germplasm collections for yield and yield components. Proceedings of the $40^{\text {th }}$ Conference of Agricultural Society of Nigeria, National Root Crops Research Institute, Umudike 16-20 October 2006. Pp. 24-27.

Agbenin, NO., Emechebe, AM., Marley, PS., Akpa, AD. (2005). Evaluation of nematicidal action of some botanicals on Meloidogyne incognita in vivo and in vitro. J. Agric. Rural Devt. Trop. and sub-Trop. 106 (1), 29-39. organic amendments should be encouraged for environmental friendliness. In the present study, crude neem leaves reduced nematode population, tuber galling and increased yield of sweet potato significantly.

out the research. We are equally indebted to the Ministry of Food and Agriculture for an effective collaboration.

Agu, CM. (2004). Effect of Meloidogyne incognita and Pratylenchus brachyurus on leaf growth of sweet potato. Tropical Science 44 (1), 48-50.

Akbar, A., Pasha, GR., Aslam, M. (2010). "Yield-density rapports: A non-parametric regression approach". International Research Journal of Finance and Economics 43,183-187.

Betiku, E., Adesina, OA. (2013). Optimization of sweet potato starch hydrolyzate production and its potential utilization as substrate for citric acid production. British Biotechnology Journal 3 (2), 169-182.

Cervantes-Flores, JC. (2000). Root-knot nematode resistance in sweet potato and development of sweet,. potato differential host genotypes for Meloidogyne spp. MSc thesis, North Carolina State University, December 2000. 
Garrido M da S., Soares ACF., Mendes L da N., Perez JO. (2003). Novas tecnologias para a produçăo do inhane (Dioscorea cayenensis) no Estado da Bahia. Revista Bahia Agricola 6, 1922.

Janssens, M. (2001). Sweet potato. In: Crop production in tropical Africa. Raemackers, R. H. (ed). DIGC. Brussels Belgium. Pp. 205-221.

Jiang, X., Jiangun, H., Wang, Y. (2005). Sweet potato processing and product research and development at the Sichuan Academy of Agricultural Sciences. File: IIA:/chapter \%209.htm.

Kaniecki, D. (2011). Sweet potato as herbal medicine. http://www.livestrong.com/article/398802-Sweet potato-herbal-medicine \#ixzz2bdxZdG89.

Khan, AA., MW, Khan. (1985). Root-knot nematodes infecting some common weeds in vegetable fields of western Uttah Pradesh, India .International Nematological Network Newsletter 2(4), 15-16.

Ludvik, B., Waldhausl, W., Prager, R., Kautzky-Willer, A., Pacini, G. (2003). Mode of action of Ipomoea batats in type 2 diabetic patients. Metabolism $52,875-880$.

Moura, RM. (1997). Doenças do inhame. In: "Manual de Fitopatologia, Sao Paulo, Ceres". H. Kimati, L. Amorin, A., Bergomin Filho, LEA., Camargo, JAM. Recande (eds), 463-471.

Pun, KB., Sabitha, D., Jeyarajan, R. (2005). Management of okra yellow vein mosaic virus disease and its white fly vector. Indian Journal of Virology 16, 32-35.

Suda, I., Yoshimoto, M., Yamakaw, O. (1999). Sweet potato potentiality. Prevention of life stylerelated disease induced by recent food habits in Japan. Food and Food Ingredients Journal 181, 59-68.

Sun, JH., Peng, DL., Yu, KL., Bi, P., Peng, YK. (1998). SEM study on tissue pathology of stem nematode disease of sweet potato. Acta Agriculturae Boreali Sinica 13,101-105

Suzuki, T., Kobayashi, T., Adachi, K., Mochida, H., Iwahori, H., Tateishi, Y., Uesugi, K. (2012). Effect of introducing resistant sweet potato cultivars on crop productivity and nematode density in sweet potato-radish double-cropping systems. Plant Production Science 15 (1), 4856.
Wang, QM., Chang, CX., Wang, JJ., Xi, GH. (1995). Identification of resistance to stem nematode in sweetpotato. Crop Genetic Research 2, 36-37.

Wang, KH. (2016). Nematode management with organic approaches. www.ctahr.hawaii.edu/Wang

Whitehead, AG., Hemming, JR. (1965). A comparison of some quantitative methods of extracting small vermiform nematodes from soil. Annals of Applied Biology 55, 25-38.

Yokoi, H., Saitsu, A., Uchida, H., Hirose, J., Hayashi, S., Takasaki, Y. (2001). Microbial hydrogen production from sweet potato starch residue. Journal of Bioscience and Bioengineering 91 (1): 58-63.

Ziska, L. 2008. Sweet potato out-yields corn in ethanol production study. Science News. http://www.sciencedaily.com/releases/2008/08/0 80825200752.html. 